\title{
Factors associated with the quality of life of older people
}

Fatores associados à qualidade de vida dos idosos

Factores asociados a la calidad de vida de las personas mayores

\section{Aurora Esteve-Clavero ${ }^{1,2}$ \\ Ana Ayora-Folch ${ }^{1}$ \\ Loreto Maciá-Soler ${ }^{3}$ \\ Maria Pilar Molés-Julio ${ }^{1}$}

\section{Keywords}

Elderly; Quality of life; Frail elderly

\section{Descritores}

Idoso; Qualidade de vida; Idoso fragilizado

\section{Descriptores}

Anciano; Calidad de vida; Anciano frágil

\section{Submitted}

July 30, 2018

\section{Accepted}

September 10,2018

\section{Abstract}

Objective: Examine the relationships between quality of life, nutrition and frailty in non-institutionalized people older than 75 years of age. Methods: Observational, cross-sectional, analytical study conducted using a questionnaire with a sample of individuals older than 75 years of age residing in the community, who were selected via convenience sampling during 2015.

Results: A larger proportion of women had poor quality of life than men: $20.9 \%$ as opposed to $9 \%(p<0.01)$. Malnutrition risk was associated with low quality of life $(35 \%)(23.4 \%)(p<0.000)$. A larger proportion of frail individuals had poor quality of life: $55.7 \%$ against $17.4 \%(p<0.000)$. Conclusion: Quality of life of older people is influenced by the presence of depression symptoms, nutritional status, sex, frailty and basic and instrumental disability.

\section{Resumo}

Objetivo: Examinar as relações entre qualidade de vida, nutrição e fragilidade em indivíduos não institucionalizados com idade acima de 75 anos. Método: Estudo observacional, transversal e analítico realizado através da aplicação de um questionário com uma amostra de indivíduos com mais de 75 anos de idade residentes na comunidade e selecionados através de amostragem por conveniência durante 0 ano de 2015

Resultados: Uma proporção maior de mulheres apresentou baixa qualidade de vida em relação aos homens: $20,9 \%$ contra 9\% ( $p<0,01)$. 0 risco de desnutrição foi associado a baixa qualidade de vida $(35 \%)(23,4 \%)(p<0,000)$. Uma proporção maior de indivíduos fragilizados apresentou baixa qualidade de vida: $55,7 \%$ contra $17,4 \%(p<0.000)$.

Conclusão: A qualidade de vida dos idosos é influenciada pela presença de sintomas de depressão, estado nutricional, sexo, fragilidade e incapacidade básica e instrumental.

\section{Resumen}

Objetivo: Examinar las relaciones entre calidad de vida, nutrición y fragilidad en individuos no institucionalizados con edad superior a 75 años. Método: Estudio observacional, transversal y analítico realizado durante el año 2015, a través de la aplicación de un cuestionario con una muestra de individuos con más de 75 años de edad residentes en la comunidad y seleccionados a través de muestreo por conveniencia.

Resultados: Una proporción mayor de mujeres presentó baja calidad de vida en relación con los hombres: 20,9\% contra 9\% $(p<0,01)$. El riesgo de desnutrición se asoció a una baja calidad de vida $(35 \%)(23,4 \%)(\mathrm{p}<0,000)$. Una proporción mayor de individuos fragilizados presentó baja calidad de vida: $55,7 \%$ contra $17,4 \%(p<0.000)$

Conclusión: La calidad de vida de los ancianos es influenciada por la presencia de síntomas de depresión, estado nutricional, sexo, fragilidad e incapacidad básica e instrumental.

\section{How to cite:}

Esteve-Clavero A, Ayora-Folch A, Mácia-Soler L, Molés-Julio MP. Factors associated with the quality of life of older people. Acta Paul Enferm. 2018;31(5):542-9.

Departamento de Enfermería, Universidad Jaume I, Castellón, Spain.

2Consellería de Sanitat, València, Spain

Departamento de Enfermerí, Universidad de Alicante, Alicante, Spain.

Conflicts to interest: none to declare. 


\section{Introduction}

The WHO defines quality of life as "an individual's perception of their position in life in the context of the culture and value systems in which they live and in relation to their goals, expectations, standards and concerns". (1) Analyzing the quality of life of older people involves understanding how they live and having information that enables assessing their degree of satisfaction according to their needs and the improvements they may require to maintain an adequate level of quality. ${ }^{(2)}$ Recent studies have examined the quality of life of older people in relation to behavior, drug prescriptions, health problems and in social terms. ${ }^{(3-7)}$ The quality of life of older people has aspects in common with that of other population groups, such as social relationships, leisure activities and satisfaction; social and environmental factors, social support, economic conditions and use of information technologies that have an important impact on the elderly. ${ }^{(8,9)}$

The most relevant differences associated with quality of life between the elderly and the rest of society can be noted in aspects related to disability and dependency. In this context, frailty is a state prior to disability and, consequently, dependency. ${ }^{(10)}$ By understanding the existence of frailty, identifying the risk factors that can trigger it and investigating it with scales and scoring instruments, it is possible to detect the frail and prefrail population. This represents a step forward in improving the quality of life of the elderly. Some studies point out that, with simple tools and adequate health promotion, it is possible to delay dependency, improve quality of life and, consequently, reduce long-term costs in social and health systems. ${ }^{(11)}$

The prevalence of frailty and its causes vary, and may be found in $5 \%$ to $58 \%$ of older people. ${ }^{(12)} \mathrm{A}$ factor that contributes to increased frailty among the elderly is having a poor nutritional status, ${ }^{(13,14)}$ which is considered a predictor of longevity and quality of life during this stage, ${ }^{(14)}$ since it is associated with physiological changes such as loss of oral function, reflected in motor activities of the mouth, such as chewing, swallowing, salivation and lack of dental parts. ${ }^{(15)}$ It is also manifested by altered or decreased discernment of the taste of foods and beverages (generally related to the consumption of certain drugs, neuropathies, gastrointestinal or endocrine disorders, inflammatory diseases, chronic diseases, neoplasms, immobility, social isolation, economic limitations and poor quality of life). ${ }^{(15,16)}$

As a result, it seems to be generalized that older people, at times, ingest less food than necessary, a situation that if persistent triggers a catabolic state that causes a progressive reduction in muscle mass, weight loss and decreased strength and functionality. ${ }^{(16,17)}$ In this sense, nutritional status plays a key role in the frailty process of older people. ${ }^{(14)}$

Given the importance of nutrition and frailty as critical elements in the quality of life of older people, the objective of this study was to analyze the relationships between quality of life, nutrition and frailty in non-institutionalized people over 75 years of age.

\section{Methods}

Observational, cross-sectional study which examined factors related to quality of life. The data were drawn from the "FRALLE Survey"(18) whitch consists of 172 questions from validated measurement instruments. It measures frailty, malnutrition risk and health-related quality of life (HRQoL). Data were collected throughout 2015. The sample was formed by non-institutionalized individuals older than 75 years of age. The study included people of both sexes, living in family dwellings, who had health cards and agreed to participate in the study, as well as people with cognitive impairment with a companion (in this case, questions regarding subjective data with were not asked). People in terminal stages of life, institutionalized, with cognitive impairment and no companion, and those who did not wish to participate were excluded. The sample was obtained through intentional sampling in nursing appointments at primary healthcare centers in the department of Castellón (Spain). A sample of 400 individuals was obtained according to the established calculation. Quality of life: measured through the Short 
Form 36 health questionnaire ${ }^{(19,20)}$ which consists of 36 items on a scale ranging from 0 (lower health status) to 100 (higher health status). The items are organized into eight dimensions, divided into two scales: a physical component (physical functioning, physical role functioning and bodily pain) and a mental component (mental health, emotional role functioning, social role functioning and vitality). Quality of life was categorized as good (score greater than or equal to 50 ) or poor (less than 50). Sociodemographics: Marital status ("Alone" for people who lived by themselves in their home and "With someone" if they lived with a family member or caregiver). Monthly income ( $<900$ euros and $>900$ euros) and sex (Female and male). Malnutrition risk: measured through the short form of the Mini Nutritional Assessment $(\mathrm{MNA}-\mathrm{SF})^{(21)}$ which consists of 6 questions with a maximum score of 14 . A score between 12 and 14 indicates "normal nutritional status", between 8 and 11 "at risk of malnutrition" and from 0 to 7 "malnourished". Frailty was defined according to the criteria of Fried et al.: ${ }^{(17)}$ Individuals were considered "frail" if they met three or more frailty criteria, "prefrail" if they met one or two criteria, and "not frail" if they did not meet any criterion. Comorbidity was measured with the Charlson index, ${ }^{(22)}$ The total score is 37 , and comorbidity is considered to be a score $\geq 3$. Basic activities of daily living (BADL): were measured with the Lawton and Brody scale. ${ }^{(23)}$ A score of 0 to 1 was considered "no or slight disability". Scores of 2 or more were considered "moderate-severe disability".

Instrumental activities of daily living (IADL). Were measured with the Lawton and Brody scale, ${ }^{(24)}$ it was categorized as: absence and instrumental disability (inability to perform 1 or more of the activities). Symptoms of depression: The Center for Epidemiologic Studies Depression Scale (CES-D) ${ }^{(25)}$ was used to measure the presence of depression symptoms. It has a questionnaire with 22 items, and a score $\geq 17$ indicates depression.

Prior to commencing the study, the Clinical Research Ethics Committee of the Department of Health of Castellón approved the study project request. The interviewees signed a free and informed consent form, and data confidentiality was preserved at all times. Descriptive analysis was performed through measures of central tendency and frequency percentages. For the bivariate analysis, Pearson's chi-square test was used for the qualitative variables, with a significance level of $\mathrm{p}<0.05$. Afterwards, a binary logistic regression multivariate analysis was performed, adding previous statistically significant results to the model. The level of non-response was assessed (those who chose not to answer certain questions in the survey or people with cognitive impairment). Taking into account that according to Demaio $^{(26)}$ when the level of non-response is below $10 \%$ an inference can be made with the available cases, it was decided not to use any imputation process. The statistical program SPSS, Version 21.0, was used for data analysis.

\section{Results}

A total of 400 individuals, 52.8\% (women), with a mean age of 81.3 years, within a range of 75 to 96 years, were interviewed. A prevalence of low quality of life was noted in the mental (8.8\%) and physical (15.3\%) components.

\section{Physical component}

Significant differences in quality of life were observed in relation to sex, in that the proportion of women with poor scores $(20.9 \%)$ was higher than men $(9 \%)(\mathrm{p}<0.01)$.

Table 1 summarizes the results obtained from the bivariate analysis for the physical component of quality of life. An association was found between malnutrition risk and quality of life. The proportion of individuals who obtained a poor score in the physical component of quality of life was higher among those with malnutrition risk or who were malnourished (35\% and $13.3 \%)$ than the proportion of individuals with good quality of life who had malnutrition risk or were malnourished $(23.4 \%$ and $1.2 \%)(\mathrm{p}<0.000)$.

In relation to frailty, the results showed that the proportion of individuals with poor quality of life increased according to the degree of frailty. The 
proportion of frail individuals with poor quality of life $(55.7 \%)$ was higher than that of frail individuals with good quality of life (17.4\%). In the case of no frailty or being in a prefrail condition, the proportion of individuals with good quality of life (25.4 and 57.2\%) was higher than that of individuals with poor quality of life (4.9 and 39.3\%, respectively) $(\mathrm{p}<0.000)$.

The presence of depression symptoms was associated with a lower score in the physical component of quality of life, in a higher proportion: $77 \%$ against $49.3 \%$ who did not have depression symptoms $(p<0.000)$. In addition, the results showed a statistically significant difference for the basic disability and instrumental disability variables, in

Table 1. Physical component of quality of life in relation to the study variables

\begin{tabular}{|c|c|c|c|c|}
\hline \multirow{3}{*}{ Variables } & \multicolumn{3}{|c|}{ Physical component } & \multirow{3}{*}{$p$-value } \\
\hline & Total & Poor & Good & \\
\hline & $n(\%)$ & $n(\%)$ & $n(\%)$ & \\
\hline \multicolumn{5}{|l|}{ Sex } \\
\hline Female & $211(52.8)$ & $44(72.1)$ & $167(49.3)$ & \multirow[t]{2}{*}{0.001} \\
\hline Male & $189(46.4)$ & $17(27.9)$ & $172(50.7)$ & \\
\hline \multicolumn{5}{|l|}{ Marital status } \\
\hline With someone & $258(64.5)$ & $43(70.5)$ & 215 (63.4) & \multirow[t]{2}{*}{0.288} \\
\hline Alone & $142(35.5)$ & $18(29.5)$ & $124(36.6)$ & \\
\hline \multicolumn{5}{|l|}{ Monthly income } \\
\hline$<900$ & 135 (41.5) & 26 (52) & 109 (39.6) & \multirow[t]{2}{*}{0.103} \\
\hline$\geq 900$ & $190(58.5)$ & $24(48)$ & $166(60.4)$ & \\
\hline \multicolumn{5}{|l|}{ Nutritional status } \\
\hline Normal & $283(71.8)$ & $31(51.7)$ & $252(75.4)$ & \multirow[t]{3}{*}{0.000} \\
\hline At risk & 99 (25.1) & $21(35)$ & 78 (23.4) & \\
\hline Malnourished & $12(3)$ & $8(13.3)$ & $4(1.2)$ & \\
\hline \multicolumn{5}{|l|}{ Frailty } \\
\hline Not frail & $89(22.3)$ & $3(4.9)$ & $86(25.4)$ & \multirow[t]{3}{*}{0.000} \\
\hline Prefrail & 218 (54.5) & $24(39.3)$ & $194(57.2)$ & \\
\hline Frail & $93(23.3)$ & $34(55.7)$ & $59(17.4)$ & \\
\hline \multicolumn{5}{|l|}{ Comorbidity } \\
\hline None & $229(57.3)$ & $29(47.5)$ & $200(59)$ & \multirow[t]{3}{*}{0.140} \\
\hline Low & $83(20.8)$ & $13(21.3)$ & $70(20.6)$ & \\
\hline High & $88(22)$ & $19(31.1)$ & $69(20.4)$ & \\
\hline \multicolumn{5}{|l|}{ Depression } \\
\hline No & $186(46.5)$ & $14(23)$ & $172(50.7)$ & \multirow[t]{2}{*}{0.000} \\
\hline Yes & 214 (53.5) & 47 (77) & $167(49.3)$ & \\
\hline \multicolumn{5}{|l|}{ Basic disability } \\
\hline None-Slight & $382(95.7)$ & $55(90.2)$ & $327(96.7)$ & \multirow[t]{2}{*}{0.019} \\
\hline Moderate-Severe & $17(4.3)$ & $6(9.8)$ & $11(3.3)$ & \\
\hline \multicolumn{5}{|l|}{ Instrumental disability } \\
\hline None & $198(50.5)$ & $22(37.9)$ & $176(52.7)$ & \multirow[t]{2}{*}{0.038} \\
\hline Moderate-Severe & 194 (49.5) & $36(62.1)$ & $158(47.3)$ & \\
\hline
\end{tabular}

that the proportion of individuals with basic disability for activities of daily living (moderate-severe) obtained worse quality of life scores $(9.8 \%)$ than individuals with no or slight disability (3.3\%) $(\mathrm{p}=0.019)$. A good score in physical quality of life was associated with no or slight basic disability (99\%) ( $\mathrm{p}=0.019)$. The proportion of individuals with instrumental disability who had poor quality of life in the physical components was higher: $62.1 \%$ as opposed to those who did not $47.3 \%$ $(\mathrm{p}=0.46)$.

No association was found for the comorbidity and sociodemographic variables (marital status and income).

\section{Mental component}

For the mental health component of quality of life (Table 2), the results showed statistically significant differences in relation to sex, where women's scores were lower than men's: $22.9 \%$ vs. $77.1 \%$ respectively $(\mathrm{p}=0.003)$. There were also statistically significant differences with respect to malnutrition risk and frailty: the proportion of individuals who obtained a low score in the mental component of quality of life was higher for individuals with malnutrition risk and who were frail: $62.9 \%$ and $60 \%$, respectively $(\mathrm{p}=0.000)$.

The results indicated a significant association between quality of life and comorbidity. The proportion of individuals without any comorbidity who had a good mental component of quality of life was higher $(58.4 \%)$ than those with low or high comorbidity (21.4\% and $20.3 \%$, respectively) $(\mathrm{p}=0.026)$.

Depression was shown to be a factor associated with a low score in the mental component of quality of life in that there was a larger proportion of individuals with depression symptoms (71.9\%) with poor quality of life than individuals without any symptoms $(26.7 \%)(\mathrm{p}=0.000)$.

In relation to basic disability, the results indicated that among individuals with moderate or severe disability the proportion of poor quality of life (5.7 and $2.9 \%$ ) was higher than good quality of life $(1.5 \%$ and $0.3 \%)(p=0.028)$. 
Table 2. Mental component of quality of life in relation to the study variables

\begin{tabular}{|c|c|c|c|c|}
\hline \multirow{3}{*}{ Variables } & \multicolumn{3}{|c|}{ Mental component } & \multirow{3}{*}{$p$-value } \\
\hline & Total & Poor & Good & \\
\hline & $\mathrm{n} \%$ & $\mathrm{n}(\%)$ & $\mathrm{n}(\%)$ & \\
\hline \multicolumn{5}{|l|}{ Sex } \\
\hline Female & $211(52.8)$ & $27(77.1)$ & $184(50.4)$ & \multirow[t]{2}{*}{0.002} \\
\hline Male & $189(47.3)$ & 8 (22.9) & 181 (49.6) & \\
\hline \multicolumn{5}{|l|}{ Marital Status } \\
\hline With someone & $258(64.5)$ & $24(68.6)$ & $234(64.1)$ & \multirow[t]{2}{*}{0.598} \\
\hline Alone & $142(35.5)$ & $11(31.4)$ & $131(35.9)$ & \\
\hline \multicolumn{5}{|l|}{ Monthly income } \\
\hline$<900$ & $135(41.5)$ & $14(51.9)$ & $121(40.6)$ & \multirow[t]{2}{*}{0.256} \\
\hline$\geq 900$ & $190(58.8)$ & $13(48.1)$ & $177(59.4)$ & \\
\hline \multicolumn{5}{|l|}{ Nutritional status } \\
\hline Normal & $283(71.8)$ & $13(37.1)$ & $270(75.2)$ & \multirow[t]{3}{*}{0.000} \\
\hline Risk & $99(25.1)$ & $15(42.9)$ & $84(23.4)$ & \\
\hline Malnutrition & $12(3)$ & $7(20)$ & $5(1.4)$ & \\
\hline \multicolumn{5}{|l|}{ Frailty } \\
\hline Not frail & $89(22.3)$ & $1(2.9)$ & $88(24.1)$ & \multirow[t]{3}{*}{0.000} \\
\hline Prefrail & $218(54.5)$ & $13(37.1)$ & $205(56.2)$ & \\
\hline Frail & $93(23.3)$ & $21(60)$ & $72(19.7)$ & \\
\hline \multicolumn{5}{|l|}{ Comorbidity } \\
\hline None & $229(57.3)$ & $16(45.7)$ & $213(58.4)$ & \multirow[t]{3}{*}{0.026} \\
\hline Low & $83(20.8)$ & $5(14.3)$ & $78(21.4)$ & \\
\hline High & $88(22)$ & $14(40)$ & $74(20.3)$ & \\
\hline \multicolumn{5}{|l|}{ Depression } \\
\hline No & $186(46.5)$ & $3(8.6)$ & $183(50.1)$ & \multirow[t]{2}{*}{0.000} \\
\hline Yes & $214(53.5)$ & $32(91.4)$ & $182(49.9)$ & \\
\hline \multicolumn{5}{|l|}{ Basic disability } \\
\hline None-Slight & $382(95.7)$ & $32(91.4)$ & $350(96.2)$ & \multirow[t]{2}{*}{0.186} \\
\hline Moderate-Severe & $17(4.3)$ & $3(8.6)$ & $14(3.8)$ & \\
\hline \multicolumn{5}{|l|}{ Instrumental disability } \\
\hline None & $198(50.5)$ & $17(51.5)$ & $181(50.4)$ & \multirow[t]{2}{*}{0.904} \\
\hline Moderate-Severe & 194 (49.5) & $16(48.5)$ & $178(49.6)$ & \\
\hline
\end{tabular}

When analyzing the effect of the variables associated with the components of quality of life, in the estimated model (Table 3), the variables that explained the physical component of quality of life were frailty and basic disability. The risk of having poor physical quality of life was 1.5 times higher among older frail people than non-frail $(\mathrm{OR}=1.566, \mathrm{CI}=0.047-0.924)$ and the risk of having a poor score in the physical component of quality of life was 0.6 times higher among older people with a basic disability for activities of daily living. For the mental component of quality of life (Table $3)$, the variables that explain it are nutritional status $(\mathrm{OR}=1.393, \mathrm{CI}=0.107-0.579)$ and depression symptoms $(\mathrm{OR}=1.223, \mathrm{CI}=0.130-0.664)$.
Table 3. Associated factors with physical and mental components of quality of life

\begin{tabular}{lccc}
\hline Variables & \multicolumn{3}{c}{ Physical component } \\
& OR & 95\% Cl & p-value \\
\hline Basic disability & 0.643 & $1.173-3.085$ & 0.009 \\
Instrumental disability & 0.069 & $0.853-1.345$ & 0.555 \\
Depression & 0.596 & $0.282-1.074$ & 0.080 \\
Nutritional status & 0.357 & $0.349-1.402$ & 0.314 \\
Frailty & 1.566 & $0.047-0.924$ & 0.039 \\
Sex & 0.749 & $0.210-1.064$ & 0.070 \\
\hline Variable & & Mental component & \\
\hline Depression & $\mathbf{0 R}$ & $95 \% \mathrm{Cl}$ & $p$-value \\
\hline Nutritional status & 1.393 & $0.107-0.579$ & 0.001 \\
Comorbidity & 1.223 & $0.130-0.664$ & 0.003 \\
Frailty & 0.552 & $0.258-1.285$ & 0.178 \\
Sex & 17.84 & $0.000-$ & 0.997 \\
\hline
\end{tabular}

Odds Ratio (OR); Confidence interval of $95 \%(95 \% \mathrm{Cl})$

\section{Discussion}

Although there are numerous instruments for measuring HRQoL, the SF-36 was chosen for the present study because it is widely used for its internal consistency and reliability. In this study, the prevalence of poor quality of life for both components was low, comparable to the results of the study by Jürschik et al.(18). These results may be explained by the fact that the study did not include institutionalized individuals, among whom there might have been a higher prevalence of poor quality of life, and because the study was conducted in a medium-sized city, comparable to results obtained in rural settings. ${ }^{(27,28)}$

There is abundant literature that shows an association between low scores for perception of quality of life in the two components and the female sex, ${ }^{(29-31)}$ which coincides with the findings of the present study. This data could explain, as in the case of the authors cited, why women view aging as a negative factor in life, and men adapt better to this process.

Although the present study was not able to establish an association between quality of life and monthly income, Morcillo et al., ${ }^{(32)}$ Ploubidis et al. and Coronado et al. ${ }^{(31,33)}$ found that quality of life was worse among older people with lower monthly income. This may be because the level of non-re- 
sponse on this point was high in the sample of the present study.

As in the present study, it has been observed that health-related quality of life is impacted by multiple pathologies, ${ }^{(34)}$ although it is also related to a decrease in the two components of HRQoL in patients with only one pathology, ${ }^{(35,36)}$ generally associated with chronic conditions. It is important to note that an association was found in the elderly population of Castellón between the mental component of quality of life and comorbidity, as in a study conducted in Tarragona with an adult population. ${ }^{(37)}$

Another factor that is associated with quality of life is depression, which in the present study had an influence on the two components, as was also found in studies by Coronado et al. and Capote et al. ${ }^{(30,31)}$

In addition, an association between basic and instrumental disability and the physical component of HRQoL has been observed. This may be because diseases appear in advanced ages and can result in the functional and mental deterioration of older people, creating dependence in activities of daily living and placing restrictions on autonomy, as was also concluded by Coronado et al. ${ }^{(31)}$

The relationships found between frailty and quality of life are similar to those in a study by Toledo. ${ }^{(38)}$ In the present study, a positive causal relationship was found among quality of life, frailty, and basic disability in the physical component and between nutritional status and depression symptoms in the mental component, which confirms that quality of life in the elderly population of Castellón was influenced by multiple factors, both sociodemographic and health-related, as was also the case in the study by Miranda et al. ${ }^{(39)}$

The findings underscore the role of frailty and basic disability on the physical component of quality of life, and nutritional status and depression on the mental component of quality of life, thus identifying these variables as important areas of intervention for improving health outcomes. ${ }^{(40,41)}$

Although there are numerous studies on quality of life, the results of this study emphasize the importance of assessing and addressing the negative perception that older people have of them- selves, and determining which factors influence this perception. Health promotion is an interdisciplinary concept, and the function of nurses is essential since they are the professionals who most frequently care for older people living at home. It is important that nurses assess the quality of life of their older patients and implement interventions to improve quality of life.

A limitation of the study was the low number of centers that participated in it. Even though it did not represent all the centers from the department, the sample obtained was representative of sociodemographic characteristics. There were also losses that occurred in the answers to the survey's subjective questions, since the participants with cognitive impairment could not answer them.

\section{Conclusion}

Most of the older people in Castellón living in the community had good quality of life. The quality of life of the older people was influenced by the presence of depression symptoms, nutritional status, sex, frailty and basic and instrumental disability. Frailty, basic and instrumental disability and sex increased the probability of poor quality of life in the physical component. Nutritional status, comorbidity, depression symptoms and sex increased the probability of poor quality of life in the mental component.

\section{Collaborations}

Esteve-Clavero A, Ayora-Folch A, Mácia-Soler L and Molés-Julio MP contributed with project and interpretation of data, writing of the article, critical review of the intellectual content and final approval of the version to be published.

\section{References}

1. Casado J, Gonzalez N, S M, Orueta R, Carmona J, RM GC. Calidad de vida relacionada con la salud en pacientes ancianos en atención primaria. Atención Primaria. 2001;28(3):47-55. 
2. Munita P. Calidad de vida y vejez. Quality. 1994;2001(26):582-4.

3. Gois AC, Pernambuco LA, Lima KC. Factors associated with voice disorders among the elderly: a systematic review. Braz J Otorhinolaryngol. 2018 ;84(4):506-513.

4. Sluggett JK, Chen EYH, Ilom?ki J, Corlis M, Hilmer SN, Van Emden $J$, et al. SImplification of Medications Prescribed to Long-term care Residents (SIMPLER): study protocol for a cluster randomised controlled trial. Trials. 2018;19(1):37.

5. Irish J, Sandhu N, Simpson C, Wood R, Gilbert R, Gullane P, et al. Quality of life in patients with maxillectomy prostheses. Head Neck. 2009;31(6):813-21.

6. Di Gessa G, Corna L, Price D, Glaser K. The decision to work after state pension age and how it affects quality of life: evidence from a 6-year English panel study. Age Ageing. 2018;47(3):450-7.

7. Koo KM, Park CH, Kim CJ. Development of strategies for changing in physical activity behaviors on older adults with disabilities. J Exerc Rehabil. 2017;13(6):676-83.

8. Ap?stolo J, Cooke R, Bobrowicz-Campos E, Santana S, Marcucci M, Cano $A$, et al. Effectiveness of interventions to prevent pre-frailty and frailty progression in older adults. JBI Database Syst Rev Implement Reports. 2018;16(1):140-232.

9. Khalaila R, Vitman-Schorr A. Internet use, social networks, loneliness, and quality of life among adults aged 50 and older: mediating and moderating effects. Qual Life Res. 2018;27(2):479-89.

10. Salado Morales L. La Fragilidad en el anciano. Cantabria: Universidad de Cantabria; 2014.

11. Behm L, Eklund K, Wilhelmson K, Zidén L, Gustafsson S, Falk K, et al. Health Promotion Can Postpone Frailty: Results from the RCT Elderly Persons in the Risk Zone. Public Health Nurs. 2016;33(4):303-15.

12. Sternberg SA, Wershof Schwartz A, Karunananthan S, Bergman $H$, Mark Clarfield $A$. The identification of frailty: a systematic literature review. J Am Geriatr Soc. 2011;59(11):2129-38.

13. Ahmed T, Haboubi N. Assessment and management of nutrition in older people and its importance to health. Clin Interv Aging. 2010;5:207-16.

14. Abellan Van kan G, Vellas B. Is the Mini Nutritional Assessment an appropriate tool to assess frailty in older adults? J Nutr Health Aging. 2011;15(3):3.

15. Vafaei Z, Mokhtari H, Sadooghi Z, Meamar R, Chitsaz A, Moeini M. Malnutrition is associated with depression in rural elderly population. $J$ Res Med Sci. 2013;18 Suppl 1:S15-9.

16. van Asselt DZ, van Bokhorst-de van der Schueren MA, van der Cammen TJ, Disselhorst LG, Janse A, Lonterman-Monasch S, et al. Assessment and treatment of malnutrition in Dutch geriatric practice: consensus through a modified Delphi study. Age Ageing. 2012;41(3):399-404.

17. Fried LP, Tangen CM, Walston J, Newman AB, Hirsch C, Gottdiener J, et al.; Cardiovascular Health Study Collaborative Research Group. Frailty in older adults: evidence for a phenotype. J Gerontol A Biol Sci Med Sci. 2001;56(3):M146-56.

18. Jürschik $P$, Nunin $C$, Botigué $T$, Escobar MA, Lavedán $A$, Viladrosa $M$. Prevalence of frailty and factors associated with frailty in the elderly population of Lleida, Spain: the FRALLE survey. Arch Gerontol Geriatr. 2012;55(3):625-31.

19. Ware JE, Sherbourne CD. The MOS 36-item short-form health survey (SF-36). I. Conceptual framework and item selection. Med Care. 1992;30(6):473-83.
20. Alonso J, Prieto L, Antó JM. La versión española del SF-36 Health Survey (Cuestionario de Salud SF-36): un instrumento para la medida de los resultados clínicos. Med Clin (Barc). 1995;104(20):771-6.

21. Vellas B, Guigoz Y, Garry PJ, Nourhashemi F, Bennahum D, Lauque $\mathrm{S}$, Albarede JL. The Mini Nutritional Assessment (MNA) and its use in grading the nutritional state of elderly patients. Nutrition. 1999;15(2):116-22. Review.

22. Charlson ME, Pompei $P$, Ales KL, MacKenzie CR. A new method of classifying prognostic comorbidity in longitudinal studies: development and validation. J Chronic Dis. 1987;40(5):373-83.

23. Katz S, Ford AB, Moskowitz RW, Jackson BA, Jaffe MW. Studies of illness in the aged: the index of ADL: a standardized measure of biological and psychosocial function. JAMA. 1963;185(12):914-9.

24. Lawton MP, Brody EM. Assessment of older people: self-maintaining and instrumental activities of daily living. Gerontologist. 1969;9(3):179-86.

25. Radloff $L$. The CES-D scale a self-report depression scale for research in the general population. Appl Psychol Meas. 1977;1(3):385-401.

26. Sanchez Carrión J. La bondad en la encuesta, el caso de la no respuesta. Madrid: Alianza Editorial; 2000. 120 p.

27. Wedgeworth M, LaRocca MA, Chaplin WF, Scogin F. The role of interpersonal sensitivity, social support, and quality of life in rural older adults. Geriatr Nurs. 2017;38(1):22-6.

28. dos Santos Tavares DM, Fernandes Bolina A, Aparecida Dias F, dos Santos Ferreira PC, José Haas V. Quality of life of elderly. Comparison between urban and rural areas. Invest Educ Enferm. 2014;32(3):40113.

29. García HI, Vera C Y, Lugo LH. Calidad de vida relacionada con la salud en Medellín y su área metropolitana, con aplicación del SF- 36. Rev Fac Nac Salud Pública. 2013;32(1):26-39.

30. Capote Leyva E, Casamayor Laime Z. Castaner Moreno J. Calidad de vida y depresión en el adulto mayor con tratamiento sustitutivo de la función renal. Rev Cuba Med Mil. 2012;41(3):237-47.

31. Coronado G. Ivez JM, Díaz Vélez C, Apolaya Segura MA, Manrique González LM, Arequipa Benavides JP. Percepción de la calidad de vida relacionada con la salud del adulto mayor residente en la ciudad de Chiclayo. Acta Méd Peru. 2009;26(4):230-8.

32. Morcillo Cebolla V, de Lorenzo-Cáceres Ascanio A, Domínguez Ruiz de León P, Rodríguez Barrientos R, Torijano Castillo MJ. Desigualdades en la salud autopercibida de la población española mayor de 65 años. Gac Sanit. Sociedad Española de Salud Pública y Administración Sanitaria. 2014;28(6):511-21.

33. Ploubidis GB, Dale C, Grundy E. Later life health in Europe: how important are country level influences? Eur J Ageing. 2012;9(1):5-13.

34 Naveiro-Rilo JC, Diez-Juárez D, Flores-Zurutuza ML, Javierre Pérez P, Alberte Pérez C, Molina Mazo R. La calidad de vida en ancianos polimedicados con multimorbilidad. Rev Esp Geriatr Gerontol. Elsevier; 2014;49(4):158-64.

35. Wu JR, Lennie TA, Frazier SK, Moser DK. Health-related quality of life, functional status, and cardiac event-free survival in patients with heart failure. j Cardiovasc Nurs. 2016;31(3):236-44.

36. Barros Hlggins L, Herazo Beltrán Y, Aroca Martínez G, Martínez GA. Calidad de vida relacionada con la salud en pacientes con enfermedad renal crónica. Rev la Fac Med. 2015;63(4):641-7.

37. Aragonès E, Lluís Piñol J, Labad A. Comorbilidad de la depresión mayor con otros trastornos mentales comunes en pacientes de atención primaria. Atención Primaria. Elsevier Doyma; 2009;41(10):545-51. 
38. Orueta Sánchez R, Rodríguez de Cossío Á, Carmona de la Morena J, Moreno Álvarez-Vijande A, García López A, Pintor Córdoba C. Anciano Frágil y Calidad de Vida. Rev Clín Med Fam. 2008;2(3):101-5.

39. Miranda LC, Soares SM, Silva PA. Qualidade de vida e fatores associados em idosos de um Centro de Referência à Pessoa Idosa. Ciênc Saude Coletiva. 2016;21(11):3533-44.
40. Akosile CO, Mgbeojedo UG, Maruf FA, Okoye EC, Umeonwuka IC, Ogunniyi A. Depression, functional disability and quality of life among Nigerian older adults: prevalences and relationships. Arch Gerontol Geriatr. 2018;74:39-43.

41. Hernández-Galiot A, Goñi I. Quality of life and risk of malnutrition in a home-dwelling population over 75 years old. Nutrition. 2017;35:81-6. 